\title{
Casein Kinase I Isoform Delta
}

National Cancer Institute

\section{Source}

National Cancer Institute. Casein Kinase I Isoform Delta. NCI Thesaurus. Code C125590.

Casein kinase I isoform delta ( $415 \mathrm{aa}, \sim 47 \mathrm{kDa}$ ) is encoded by the human CSNK1D gene.

This protein is involved in protein phosphorylation, cell survival and cellular growth. 